\title{
The effects of dietary sucrose and the concentrations of plasma urea and rumen ammonia on the degradation of urea in the
} gastrointestinal tract of cattle

\author{
BY P. M. KEN NEDY* \\ CSIRO, Tropical Cattle Research Centre, PO Box 542, \\ Rockhampton, Queensland 4700, Australia
}

(Received 4 May 1979 - Accepted 27 June 1979)

\begin{abstract}
I. The rates of entry of urea into plasma, of urea degradation in the gastrointestinal tract, and the partition of that degradation between the rumen and post-ruminal tract were determined by use of $\left[{ }^{14} \mathrm{C}\right]$ urea and $\mathrm{NaH}^{14} \mathrm{CO}_{3}$ in Hereford steers receiving hay diets with or without sucrose. The concentrations of plasma urea and rumen ammonia were varied by infusions of urea into the rumen or abomasum.

2. For all diets, plasma urea concentration was related to urea entry rate, to degradation of urea in the whole gastrointestinal tract, and to its degradation in the post-ruminal tract, but the relationship with its degradation in the rumen was poor.

3. Degradation of urea in the rumen was related in a multiple regression in a curvilinear manner in three groups of diets (pasture-hay alone, pasture-hay-lucerne (Medicago sativa) mixtures, diets with sucrose), and negatively to rumen ammonia concentration for pasture-hay diets, and diets with sucrose.

4. Ruminal clearance of urea (rate of urea degradation per plasma urea concentration) was negatively related to the rumen ammonia concentration for steers given diets with sucrose, of pasture-hay with or without urea infusions. Provision of sucrose in the diet significantly increased clearance.

5. Enhanced urea degradation in the rumen associated with dietary sucrose supplements accounted for 0.4 of additional microbial $\mathrm{N}$ synthesis in the rumen.

6. The partition of transfer of urea to the rumen via saliva and through the rumen wall is discussed.
\end{abstract}

The conclusion that ruminants conserve significant amounts of nitrogen by transfer of urea from the blood to the rumen with subsequent utilization by the bacterial population (e.g. Houpt, 1970) has not received support in some studies with sheep given good- and poorquality hay (Nolan \& Leng, I 972; Nolan et al. 1976; Norton et al. 1978). In the latter studies, quantitative estimates of the rate of transfer of urea from the blood to the rumen (i.e. degradation of endogenous urea in the rumen), made by employing radionuclide tracer techniques, indicated that salivary transport of urea could account for most of the small quantities $(0 \cdot 4-1 \cdot 2 \mathrm{~g} \mathrm{~N} / \mathrm{d})$ of urea transferred to the rumen. However, higher values $(6 \cdot 2-9 \cdot 8$ $\mathrm{g} \mathrm{N} / \mathrm{d}$ ) for urea transfer to the rumen were obtained for sheep given a pelleted grass diet; a maximum of 0.9 of the transfer was attributed to diffusion of plasma urea across the rumen epithelium (Kennedy \& Milligan, I978a). The differences between these estimates both in total urea transfer and in the proportion of urea transported via saliva appeared to be associated with differences in concentration of rumen ammonia and with amounts of organic matter (OM) digested in the stomach (Kennedy \& Milligan, 1978 $a, b$ ).

In cattle, some estimates obtained by use of tracer techniques are available for the rate of urea transfer to the whole gastrointestinal tract of dairy cows given a grain-based ration containing urea (Mugerwa \& Conrad, 197I) and to both the rumen and post-ruminal tract of cattle given low-quality sorghum stubble (Norton et al. 1979).

In the investigations now reported, the extent of transfer of plasma urea to both the rumen and post-ruminal tract of cattle under conditions of varied intakes of digestible OM

- Present address: Department of Animal Science, University of Alberta, Edmonton, Alberta, T6G 2E3, Canada. 
Table 1. Composition of experimental diets

\begin{tabular}{|c|c|c|c|c|}
\hline $\begin{array}{l}\text { Diet } \\
\text { no. }\end{array}$ & $\begin{array}{l}\text { Expt } \\
\text { no. }\end{array}$ & Constituent and daily intake $(\mathrm{kg})$ & $\begin{array}{l}\text { Dietary nitrogen } \\
\text { intake }(g / d)\end{array}$ & $\begin{array}{l}\text { A bomasal urea } \\
\text { infusion }(\mathrm{g} / \mathrm{d})\end{array}$ \\
\hline I & $\mathbf{I}$ & 3 pasture-hay* & $37 \cdot 8$ & - \\
\hline 2 & $\mathbf{I}$ & 3 pasture-hay, $28 \mathrm{~g}$ urea & $5 I \cdot 2$ & - \\
\hline 3 & $\mathbf{I}$ & 3 pasture-hay & $37 \cdot 8$ & 29 \\
\hline 4 & $\mathbf{I}$ & 3 pasture-hay, $500 \mathrm{~g}$ sucrose & $37 \cdot 8$ & 29 \\
\hline 5 & 2 & $\begin{array}{l}\text { 3.75 pasture-hay, I.25 lucerne (Medicago sativa), } \\
\mathrm{I} \cdot 00 \text { sucrose, } \mathrm{I} 6.4 \mathrm{~g} \mathrm{~K}_{2} \mathrm{SO}_{4}, 60 \mathrm{~g} \text { urea }\end{array}$ & 107 & - \\
\hline 6 & 2 & $\begin{array}{l}3.75 \text { pasture-hay, I.25 lucerne, I.00 sucrose, } \\
60 \mathrm{~g} \text { urea }\end{array}$ & 107 & - \\
\hline 7 & 2,3 & $\begin{array}{l}\text { 3.75 pasture-hay, I.25 lucerne, I } .00 \text { sucrose, } \\
\text { I6.4 } \mathrm{g} \mathrm{K}_{2} \mathrm{SO}_{4}\end{array}$ & $78 \cdot 4$ & 60 \\
\hline 8 & 2 & 5.0 pasture-hay, I sucrose, $10.0 \mathrm{~g} \mathrm{~K}_{2} \mathrm{SO}_{4}$ & $67 \cdot 2$ & - \\
\hline 9 & 2 & $\begin{array}{l}5.0 \text { pasture-hay, I sucrose, } 10.0 \mathrm{~g} \mathrm{~K}_{2} \mathrm{SO}_{4} \text {, } \\
\text { I } 20 \mathrm{~g} \text { urea }\end{array}$ & 124 & 一 \\
\hline 10 & 2 & $5 \cdot 0$ lucerne & 138 & - \\
\hline II & 2 & 2.5 pasture-hay, 2.5 lucerne & $98 \cdot 3$ & - \\
\hline 12 & 2,3 & 3.75 pasture-hay, $1 \cdot 25$ lucerne & $78 \cdot 4$ & - \\
\hline
\end{tabular}

and $\mathbf{N}$ was measured. In particular the relationship between urea degradation, plasma urea concentration, rumen ammonia concentration and fermentation of $O M$ in the rumen was studied. A preliminary report of part of this work has been published elsewhere (Kennedy, I978).

\section{EX PERIMENT AL}

\section{Cattle, diets and experiments}

Six Hereford steers (nos. I-6) were fitted with permanent cannulas in the rumen and were maintained in individual stalls between experiments and in metabolism cages during the experiments. Four of the steers were also fitted with simple abomasal cannulas, sited $40-60 \mathrm{~mm}$ from the pylorus. The steers were of average age 12 months and weight 202 $\mathrm{kg}$ in the first series and 19 months and $235 \mathrm{~kg}$ during the second and third series of experiments.

In the first series, diets nos. 1, 2 and 3 were given to three steers (nos. I-3) during three periods, each of $\mathrm{I} 4 \mathrm{~d}$, in a Latin-square design (Kennedy, 1978 ). Concurrent with the final period, three additional steers (nos. 4-6) were given diet no. 4. All animals had received pasture-hay for 4 weeks before the start of the 'Latin-square' period. The ration was given in equal amounts twice daily to steers in stalls for the first $7 \mathrm{~d}$ of the experimental period, followed by hourly feeding in equal amounts to steers in metabolism cages for the remaining $7 \mathrm{~d}$. Infusions of $\left[{ }^{14} \mathrm{C}\right]$ urea and $\left[{ }^{14} \mathrm{C}\right]$ sodium bicarbonate were made after steers had been in metabolism cages for 4 and $6 \mathrm{~d}$ respectively, in order to measure urea transactions.

In the second series of experiments, diets nos. 5-9 were given to each of two steers (nos. I and 2) according to a randomized-block design. In addition, in two successive periods, diets nos. 10 and 11 were given to two steers (nos. 3, 4 and 5, 6 respectively), followed by a period during which diet no. 12 was given to all four steers (nos. $3,4,5,6$ ). The routine followed was identical to that of the first series of experiments, with the exception that steers were given the diet in stalls for a total of $14 \mathrm{~d}$ before being removed to metabolism cages for $7 \mathrm{~d}$.

The third series of experiments comprised two experimental periods of $21 \mathrm{~d}$, in which two steers, both fitted with an abomasal cannula, were given diets nos. 7 and 12 for $1 \mathrm{I} d$ in 
stalls before being removed to metabolism cages for $10 \mathrm{~d}$. Markers were infused into the rumen over a $7 \mathrm{~d}$ period in order to measure flow of digesta through the abomasum.

The composition of the diets is given in Table I. Potassium sulphate was added in different amounts to diets containing sucrose in order to obtain different rates of ammonia utilization by rumen microbes. Urea was infused in solution $(800 \mathrm{ml}$ water/d) into the abomasum of steers given diets nos. 3,4 and 7 ).

\section{Experimental procedures}

In the first and second series of experiments, steers were prepared with catheters in each jugular vein, $2 \mathrm{~d}$ after having been removed to metabolism cages. At 17.00 hours on the third day, each steer was given an intravenous priming dose of $\left[{ }^{14} \mathrm{C}\right] \mathrm{urea}(5 \mathrm{ml}, 40 \mu \mathrm{Ci} / \mathrm{ml}$ saline $(9 \mathrm{~g}$ sodium chloride/l)) followed by a continuous infusion $(800 \mathrm{ml} / \mathrm{d}, 0.5 \mu \mathrm{Ci} / \mathrm{ml}$ saline) for $24 \mathrm{~h}$. Blood ( $10 \mathrm{ml}$ ) and rumen fluid $(20 \mathrm{ml})$ were taken at intervals of $45 \mathrm{~min}$ for the final $8 \mathrm{~h}$ of the infusion period. At $24 \mathrm{~h}$ after sampling had been completed, intraruminal infusions of $\mathrm{NaH}^{14} \mathrm{CO}_{3}(800 \mathrm{ml} / \mathrm{d}, 0.38 \mu \mathrm{Ci} / \mathrm{ml}$, I $\mathrm{mg} \mathrm{NaHCO} / \mathrm{ml})$ were started and continued for $24 \mathrm{~h}$. Blood ( $10 \mathrm{ml})$ and rumen fluid $(20 \mathrm{ml})$ were taken at intervals of $45 \mathrm{~min}$ for the final $8 \mathrm{~h}$ of the infusion period. Urine was collected over $3 \mathrm{~d}$ into hydrochloric acid for the estimation of urea excretion.

In the third series of experiments, the flow of OM, non-ammonia-N (NAN) and microbial $\mathrm{N}$ was estimated by reference to chromium complexed with EDTA (CrEDTA) (Downes \& McDonald, I964) and the tris-(I, IO-phenanthroline)-ruthenium (II) chloride complex (Ru-P) (Tan, et al. I97I). These markers were continuously infused (I $50 \mathrm{mg} \mathrm{Cr}, 50 \mathrm{mg}$ $\mathrm{Ru} / \mathrm{d}, 800 \mathrm{ml} / \mathrm{d}$ ) for $7 \mathrm{~d}$, together with $\mathrm{Na}_{2}{ }^{35} \mathrm{SO}_{4}(500 \mu \mathrm{Ci} / \mathrm{d}$ ), after a priming dose (I50 mg $\mathrm{Cr}, 50 \mathrm{mg} \mathrm{Ru}, 500 \mu \mathrm{Ci}^{35} \mathrm{~S}$ ). Abomasal digesta (400 g) were collected at 07.30, 10.30, I3.30, and 16.30 hours on the final $3 \mathrm{~d}$ of infusion and bulked and stored at $-15^{\circ}$. A supernatant fraction was later prepared by centrifuging at $650 \mathrm{~g}$ for $30 \mathrm{~min}$. The microbial component of abomasal digesta $\mathbf{N}$ was determined by reference to organic ${ }^{35} \mathrm{~S}$ in abomasal digesta and an abomasal microbial fraction prepared by differential centrifugation (Kennedy et al. I976).

\section{Analytical methods}

Urea in plasma and urine was determined by the diacetyl monoxime method of Marsh et al. ( 1957 ). The specific radioactivities of urea-C in plasma and $\mathrm{HCO}_{3}-\mathrm{C}$ in rumen fluid were determined by the methods of Cocimano \& Leng (1967) and Leng \& Leonard (1965). Ammonia concentration was determined by steam distillation over magnesium oxide with titration by $0.01 \mathrm{M}$-hydrochloric acid. Total $\mathrm{N}$ was determined using an autoanalyser (Crooke \& Simpson, 197I) after Kjeldahl digestion. Abomasal digesta and its supernatant fraction were dried at $90^{\circ}$ and the concentrations of $\mathrm{Ru}$ and $\mathrm{Cr}$ therein were determined by atomic absorption spectroscopy on samples treated according to the methods of Megarrity \& Siebert (1977) and Christian \& Coup (1954).

$\mathrm{OM}$ was determined by incineration at $600^{\circ}$ for $6 \mathrm{~h}$.

The concentration and specific radioactivity of organic ${ }^{25} \mathrm{~S}$ was determined by the methods of Bird \& Fountain (1970).

\section{Calculations}

The rates of entry of plasma urea, and of $\mathrm{HCO}_{3}{ }^{-} \mathrm{C}$ in rumen fluid, were calculated from the specific radioactivity at plateau and the isotope infusion rate during each infusion (White et al. 1969). The proportion of the secondary pool (blood or rumen fluid) derived from the primary (infused) pool (rumen fluid or blood) was determined from the relative amounts of plateau specific radioactivity in each pool during the infusion period. The rate of degradation of plasma urea in the rumen was calculated as described by Kennedy \& Milligan 
( $1978 a$ ), assuming that all blood urea-C is derived from blood carbon dioxide- $\mathrm{C}$ and that rumen fluid $\mathrm{HCO}_{3}-\mathrm{C}$ enters the blood urea-C pool via blood $\mathrm{CO}_{2}$ only. The rate of degradation of urea in the total gastrointestinal tract was estimated as the difference between urea entry and urinary urea excretion. In turn, the degradation of urea in the post-ruminal tract was estimated as the difference between urea degradation in the gastrointestinal tract and degradation in the rumen. Ruminal clearance of urea $(1 / d)$ was calculated as: $\frac{\text { rate of urea degradation in the rumen }(\mathrm{mg} \mathrm{N} / \mathrm{d})}{\text { concentration of plasma urea }(\mathrm{mg} \mathrm{N} / \mathrm{l})}$

The flows of OM, NAN and bacterial $N$ were calculated by reference to CrEDTA and Ru-P as described by Faichney (1975).

\section{Statistical analysis}

Values from the Latin-square (diets nos. I-3) and the randomized-block (diets nos. 5-9), were analysed separately by analysis of variance. Large variation between animals within treatments was observed for some variables, leading to large standard errors of treatment means. However, since analysis indicated that between-animal effects were not a source of bias in the relationships between the variables of interest (i.e. the slopes of the relationships between the pairs of variables were similar in both the 'animal' line and the 'diet' line in a simultaneous analysis of variance of the variable pair (Seebeck, I979)), regressions were fitted to the raw values within groups of diets. Polynomial terms were included if they reached significance $(P<0.05)$ (terms up to the fourth power were tested). Where slopes were not significantly different $(P<0.05)$, the common regression was used. For the regression between urea entry rate and plasma urea concentration, logarithmic transformation of both variables appeared appropriate since the variance was approximately proportional to the mean and the regression tended towards the origin.

\section{RESULTS}

Plasma urea concentration, urea entry rate and urea degradation

The mean values (diets nos. I-9 and I2) and individual values (diets nos. 10 and II) for urea movements are given in Tables 2 and 3. Differences in urea metabolism between steers given the same diet were reflected primarily in plasma urea concentration and entry rate; the relationship between these two variables is shown in Fig. I. The logarithmic common regression with intercepts calculated for each dietary group, between urea entry rate $(E, \mathrm{~g} \mathrm{~N} / \mathrm{d})$ and plasma urea concentration $(U, \mathrm{mg} \mathrm{N} / \mathrm{l})$ for diets with or without sucrose were:

with sucrose, diets nos. 4-9 $\log _{10} E=-0.0209+0.840 \log U$, no sucrose, diets nos. $\mathrm{I}-3$ and $10-12 \log _{10} E=-0.150+0.840 \log U$.

At a given concentration of plasma urea, the mean entry rate of urea in steers given sucrose was $35 \%$ higher than in steers given diets without sucrose.

Degradation of plasma urea in the gastrointestinal tract was closely related to plasma urea concentration (Fig. 2) for diets with or without sucrose. At concentrations of less than $200 \mathrm{mg}$ urea-N/l, there was more degradation of urea in cattle given diets with sucrose.

For diets containing sucrose, the proportion of urea entering the plasma urea pool and which was subsequently degraded was highest, 0.88 , for steers given the diet of hay without urea (diet no. 8) and was lowest, $0.46-0.47$, for steers given dietary urea (diets nos. 6 and 9 ). For diets without sucrose, this proportion was highest, $0.62-0.67$, for steers given lucerne 


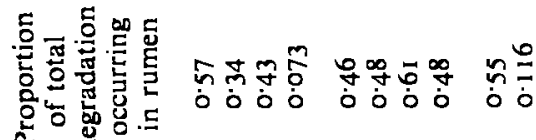

을

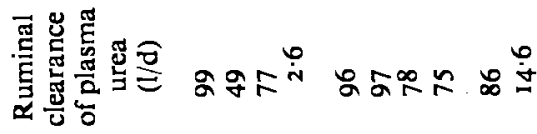

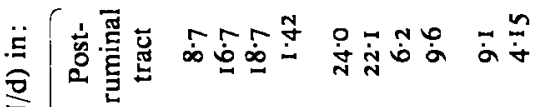

豆

o 0

2

ㄴ.

范

ป

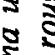

ป.

ช

$.2 \frac{2}{2}$

ป 5

2

ฐ

b

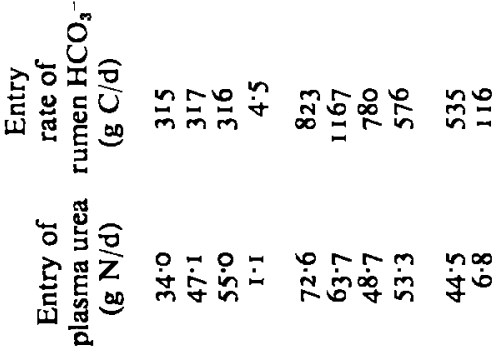

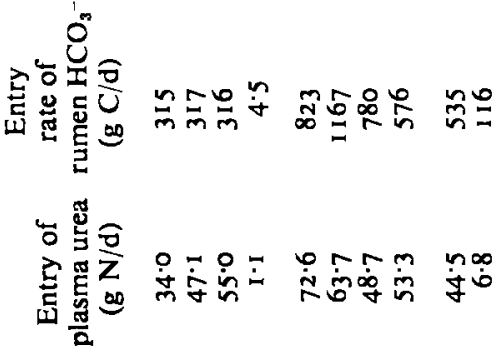

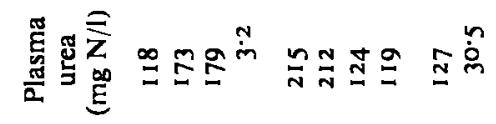

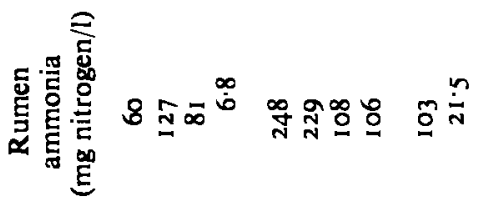

苟

岛
จ

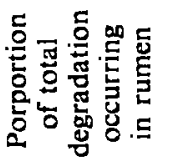

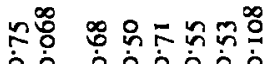

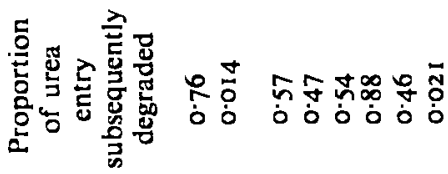

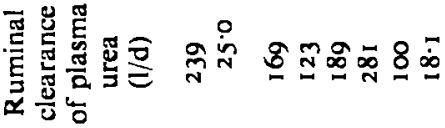

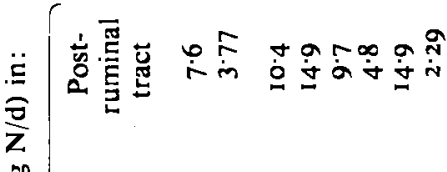

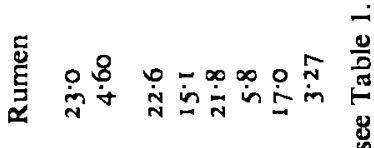

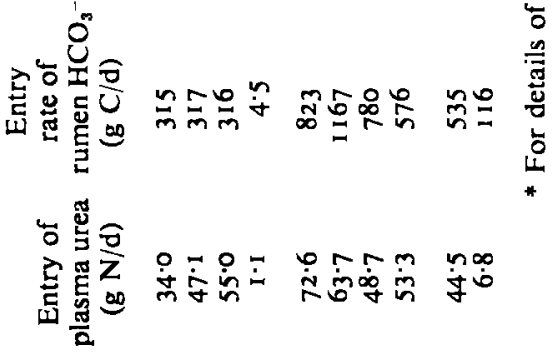

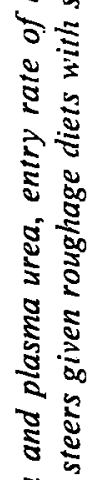

ב⿱

I

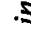

$\frac{2}{2}$

ปั

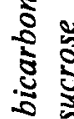

:

ป

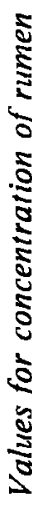

$\stackrel{\check{2}}{\stackrel{0}{0}}$

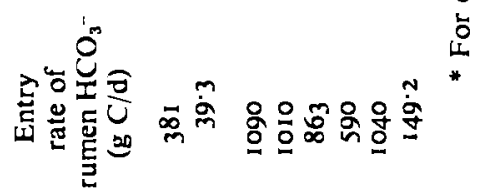

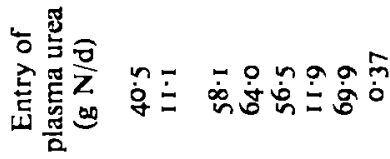

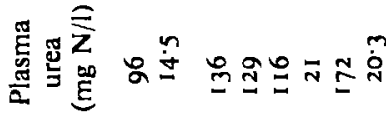

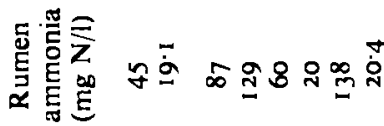

离 


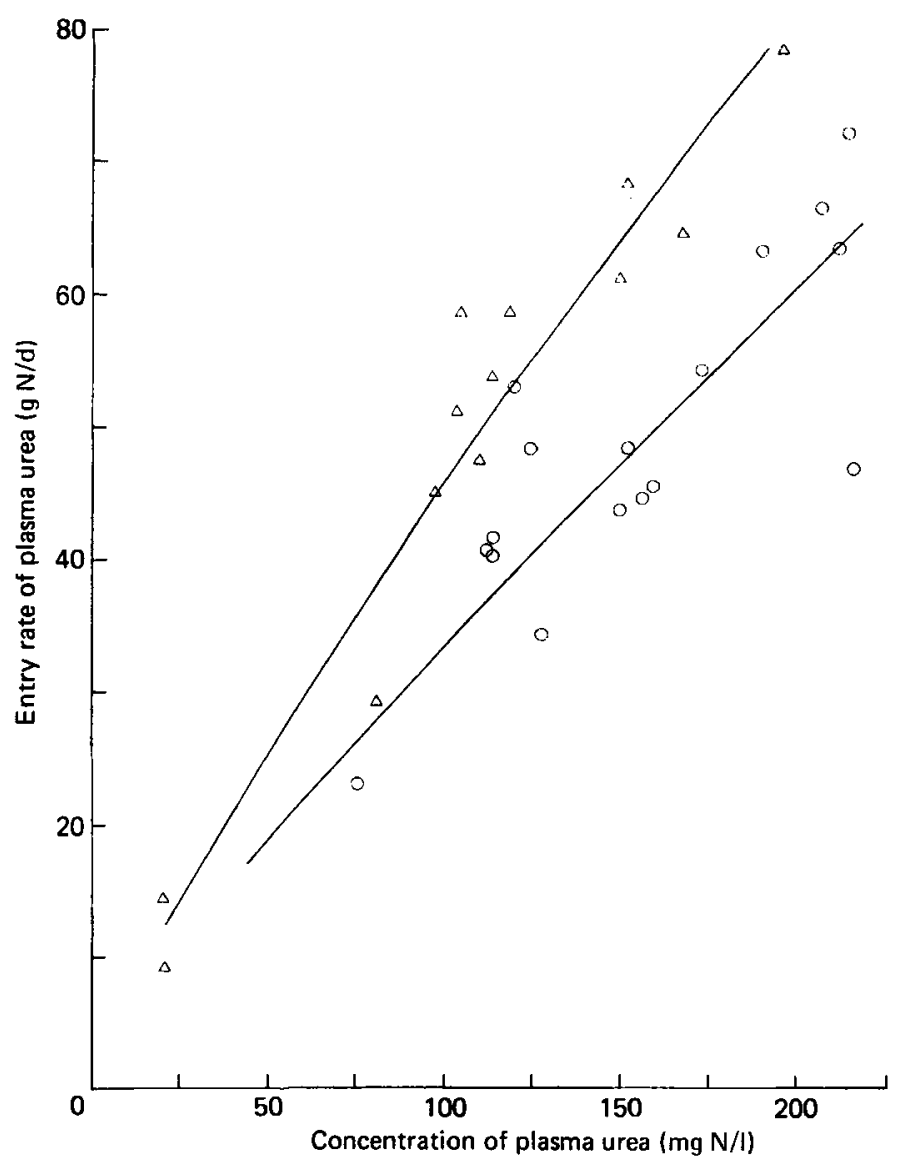

Fig. 1. The relationship between urea entry rate ( $g$ nitrogen/d) and plasma urea concentration (mg $\mathrm{N} / \mathrm{l}$ ) for steers given diets with sucrose $(\triangle$, diets nos. $4-9)$ or without sucrose $(0$, diets nos. $\mathrm{I}-3$ and 10-12). For details of diets, see Table 1. The regression equations were:

$\begin{aligned} & \text { diet nos. } 4-9 \quad y=0.953 x^{0.840} \\ & \text { diet nos. } 1-3 \text { and } 10-12 \quad y=0.707 x^{0.840} \text { (Common residual sD antilog } 0.068=1 \cdot 169, R 0.94 \text { ). }\end{aligned}$

(Medicago sativa) hay (diet no. 10), and was lowest (0.34), for steers given lucerne-pasture (diet no. I 1 ) (Tables 2, 3).

Degradation of urea in the post-ruminal tract was closely related to plasma urea concentration (Fig. 3). Degradation of urea in the rumen was closely related to plasma urea concentration for diets not containing urea or sucrose (diets nos. I and I0-12) but the relationship was poor for pasture-hay diets (diets nos. I-3), diets with sucrose (diets nos. 4-9) and for all diets (diets nos. I-I2) (Table 4). Inclusion of the quadratic term markedly improved the precision of the relationship for diets with sucrose (Table 4).

The relationships of urea degradation in the rumen, post-ruminal and total gastrointestinal tract with plasma urea entry were markedly different between steers given diets with sucrose and steers given pasture-hay without lucerne (Fig. 4). In particular, urea degraded in the rumen comprised a greater proportion of the plasma urea entry and of degradation in the gastrointestinal tract of cattle given sucrose than of cattle given the pasture-hay diets (Fig. 4a). Rumen degradation accounted for $0.50-0.75$ of urea degraded 


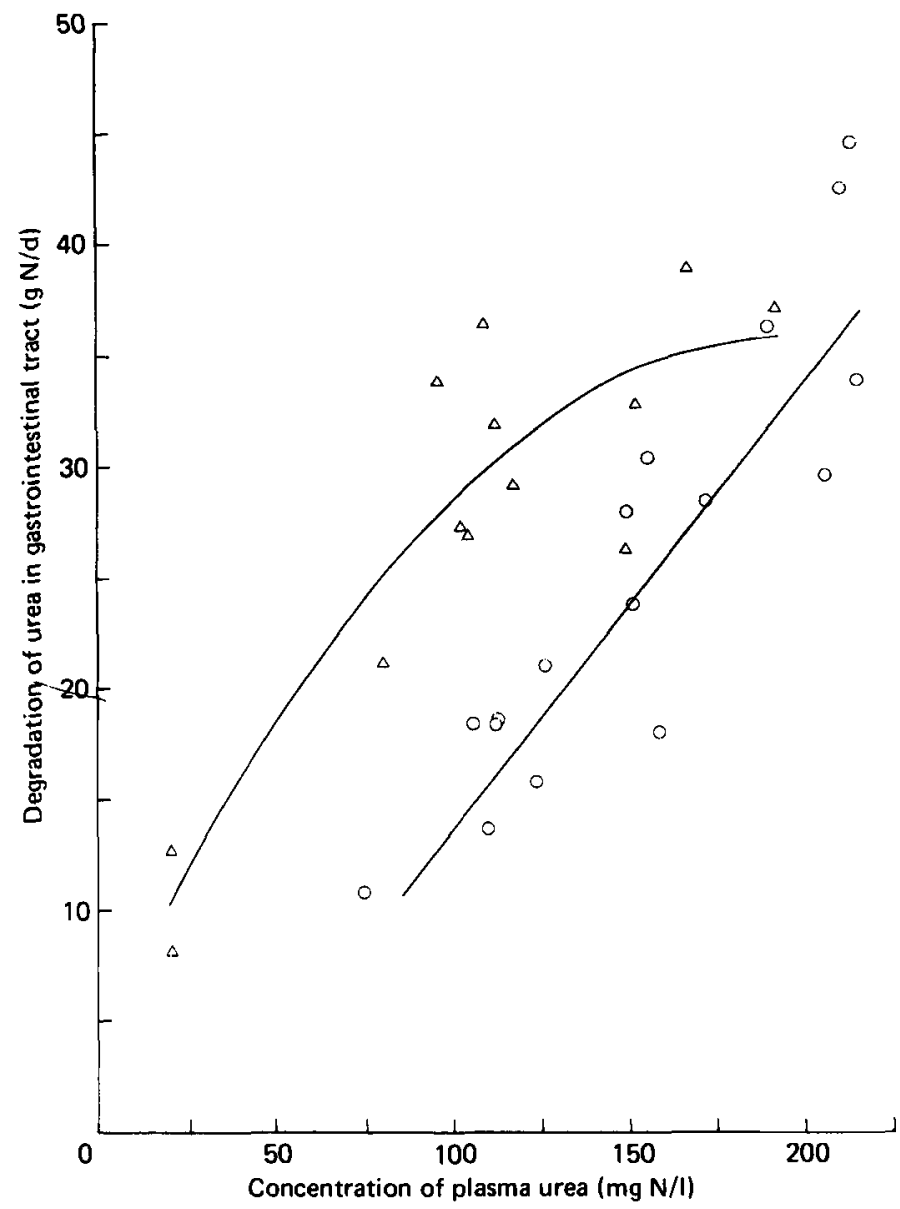

Fig. 2. The relationship between degradation rate of urea in the gastrointestinal tract ( $\mathrm{g}$ nitrogen/d) and plasma urea concentration ( $\mathrm{mg} N / \mathrm{l})$ for steers given diets with $(\Delta$, diets nos. 4-9) or without $(O$, diets nos. $1-3$ and $10-12)$ sucrose. For details of diets, see Table 1 . The relationships were described by the equations:

diet nos. 4-9 $y=4.44+0.321 x-0.000813 x^{2}$ (residual SD (RSD) 4.47, $R \quad 0.90$ ), ciet nos. I-3 and 10-12 $y=-7.03+0.212 x$ (RSD 4:I2, $R$ 0.92)

in the gastrointestinal tract of cattle given sucrose, compared to values of $0.34-0.61$ in steers without sucrose (Tables 2 and 3). In addition, the curvilinear relationship, in which urea entry rates of $>50 \mathrm{gN} / \mathrm{d}$ were associated with a decrease of urea degradation in the rumen of cattle given sucrose, was not apparent in cattle given pasture-hay diets (Fig. $4 b$ ).

\section{Degradation of urea in the rumen, ruminal clearance of urea, and rumen ammonia} concentration

There was no simple relationship between degradation of urea in the rumen and rumen ammonia concentration, except perhaps in diets without sucrose or urea (diets nos. 10-12) (Fig. 5). Alternatively, the relationships could be considered to be described by a 'family of lines', with the relative position of each line determined by the composition of the basal diet (Fig. 5). 


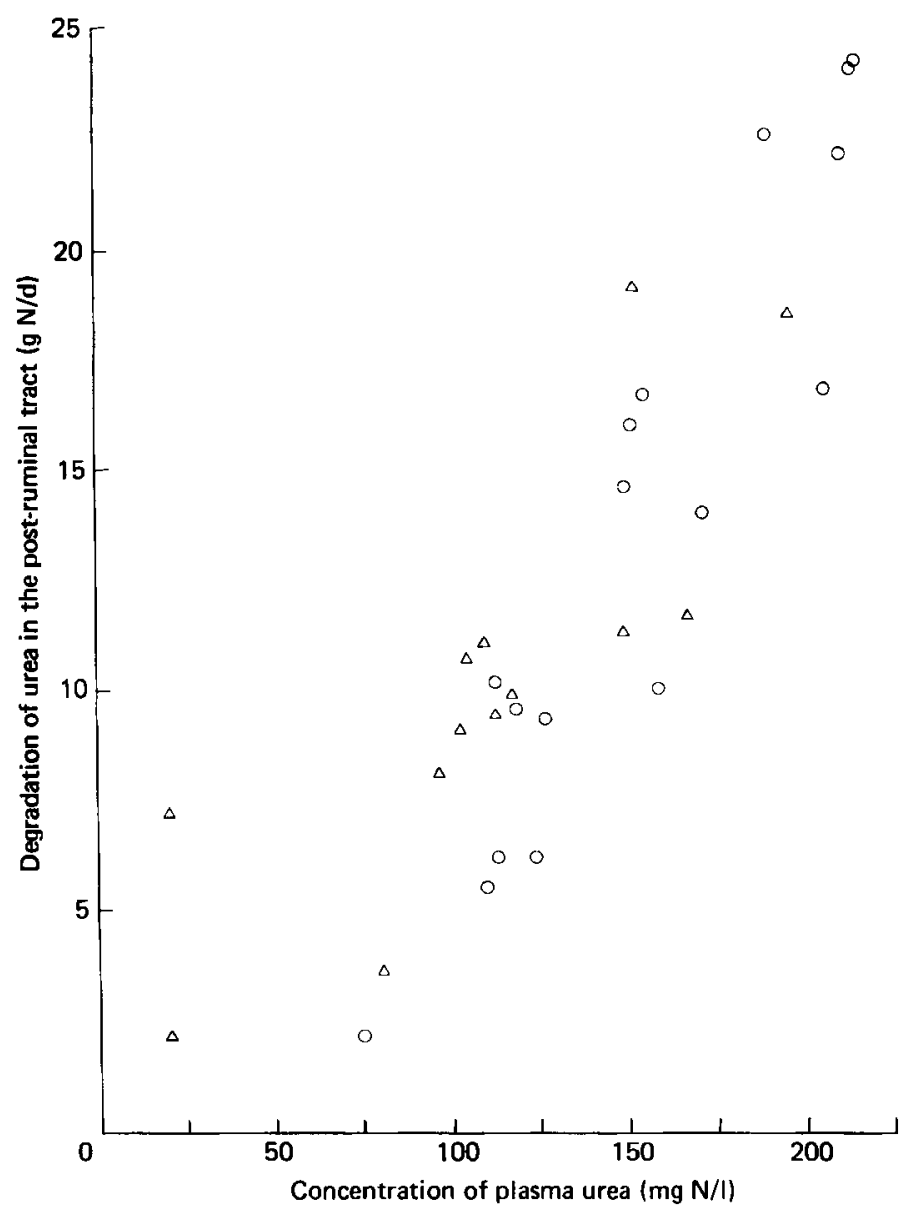

Fig. 3. The relationship between degradation rate in the post-ruminal tract ( $\mathrm{g}$ nitrogen/d) and plasma urea concentration $(\mathrm{mg} N / \mathrm{l})$ for steers given diets with sucrose $(\Delta$, diets nos. $4-9)$ or without sucrose $(O$, diets nos. $I-3$ and $10-12)$. For details of diets, see Table 1 .

Fig. 4(a) Relationships in cattle given diets with sucrose (diets nos. 4-9) between the degradation rate of urea (g nitrogen/d) in the gastrointestinal tract $(\bullet)$, in the rumen $(\Delta)$ and in the postruminal tract $(\Delta)$ and the entry rate of plasma urea $(\mathrm{g} \mathrm{N} / \mathrm{d})$. The relationships were described by the equations:

$$
\begin{aligned}
\text { gastrointestinal tract } & y=1.82+0.864 x-0.00551 x^{2} \quad \text { (residual SD (RSD) 4.53, } R 0.89 \text { ), } \\
\text { rumen } & y=-3.22+0.952 x-0.00914 x^{2} \quad \text { (RSD 4.53, } R 0.80 \text { ), } \\
\text { post-ruminal tract } & y=4.93-0.0947 x+0.00350 x^{2} \quad \text { (RSD 2.22, } R 0.91 \text { ). }
\end{aligned}
$$

(b) Relationships in cattle given diets without sucrose or lucerne (Medicago sativa) (diets nos. $\mathrm{I}, 2$ and 3 ) between the degradation rate of urea $(\mathrm{g} \mathrm{N} / \mathrm{d})$ in the gastrointestinal tract $(\bullet)$, in the rumen $(\triangle)$ and in the post-ruminal tract $(\Delta)$, and entry rate of plasma urea $(\mathrm{g} \mathrm{N} / \mathrm{d})$. The relationships were described by the equations:

$$
\begin{aligned}
\text { gastrointestinal tract } & y=-0.914+0.594 x \quad \text { (residual SD (RSD) 4.97, } R 0.83 \text { ), } \\
\text { rumen } & y=6.26+0.112 x \text { (RSD 2.60, } R \quad 0.47 \text { ), } \\
\text { post-ruminal tract } & y=-7.17+0.482 x \quad \text { (RSD 4.19, } 0.82 \text { ). }
\end{aligned}
$$

For details of diets, see Table I. 


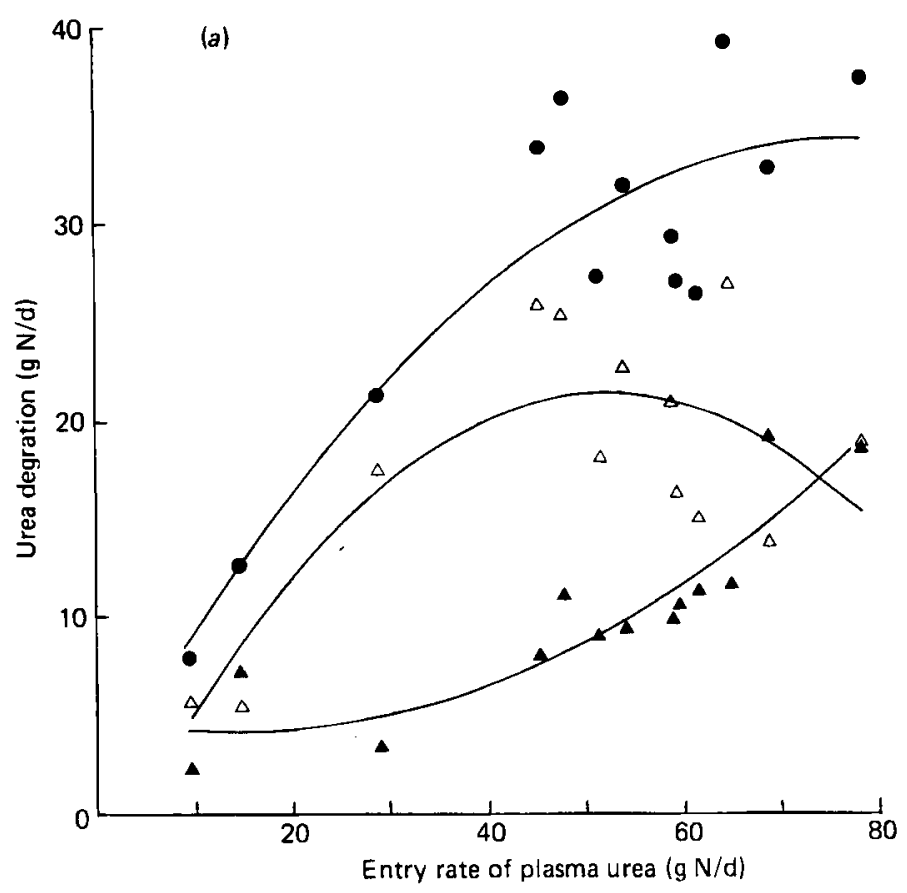

Fig. 4(a)

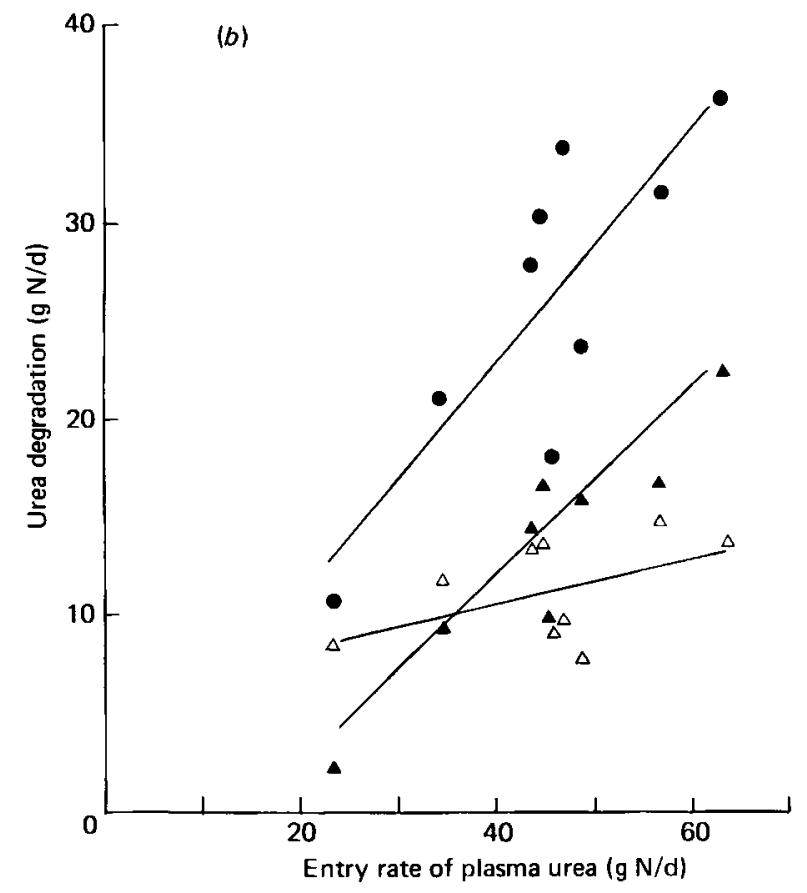

Fig. 4(b) 
Table 4. Regressions relating urea degradation in the rumen (Dr, g nitrogen/d) to plasma urea concentration $(\mathrm{U}, \mathrm{g} N / l)$ and rumen ammonia concentration $(\mathrm{A}, \mathrm{g} N / l)$

Diet no.

$$
\mathbf{I}-\mathbf{3}
$$

4-9

I-1 2

I, 10-12
Regression equation

$$
\begin{aligned}
& D r=7 \cdot 40+24 \cdot 7 U \\
& D r=4 \cdot 07+73 \cdot 2 U-162 \cdot 5 U^{2} \\
& D r=10 \cdot 2+53 \cdot 1 U-81 \cdot 7 A \\
& D r=1 \cdot 06+194 U-461 U^{2}-91 \cdot 7 A
\end{aligned}
$$

$$
\begin{aligned}
& D r=-0 \cdot 88 \mathrm{I}+96 \cdot 0 U \\
& D r=10 \cdot 6-68 \cdot 3 U+538 U^{2} \\
& D r=-0 \cdot 25+83 \cdot 3 U+9 \cdot 80 A \\
& D r=12 \cdot 8-93 \cdot 7 U+682 U^{2}-14 \cdot 3 A
\end{aligned}
$$$$
\text { Dr }=9 \cdot 27+78.7 U
$$$$
D r=0.413+310 U-1143 U^{2}
$$$$
D r=8.03+195 U-152 A
$$$$
D r=-0.308+410 U-1082 U^{2}-147 A
$$$$
D r=4 \cdot 79+7 \mathrm{I} \cdot 5 \mathrm{U}
$$$$
D r=-0.528+170 U-385 U^{2}
$$$$
D r=4 \cdot 11+104 U-39 \cdot 5 A
$$$$
D r=-0.415+185 U-334 U^{2}-34.3 A
$$

NS, not significant.

$* P<0.05$, *** $P<0.001$.
Residual SD

$R \quad P$
$0.387 \quad N S$
$0.408 \quad N S$
$0.882^{* * *}$
$0.949^{* * *}$
$0.942^{* * * *}$
$0.966^{* * * *}$
$0.944^{* * *}$
$0.969^{* * *}$
$0.586^{*}$
$0.777^{* * *}$
$0.861^{* * *}$
$0.987^{* * *}$
$0.638^{* * *}$
$0.685^{* * *}$
$0.685^{* * *}$
$0.718^{* * *}$

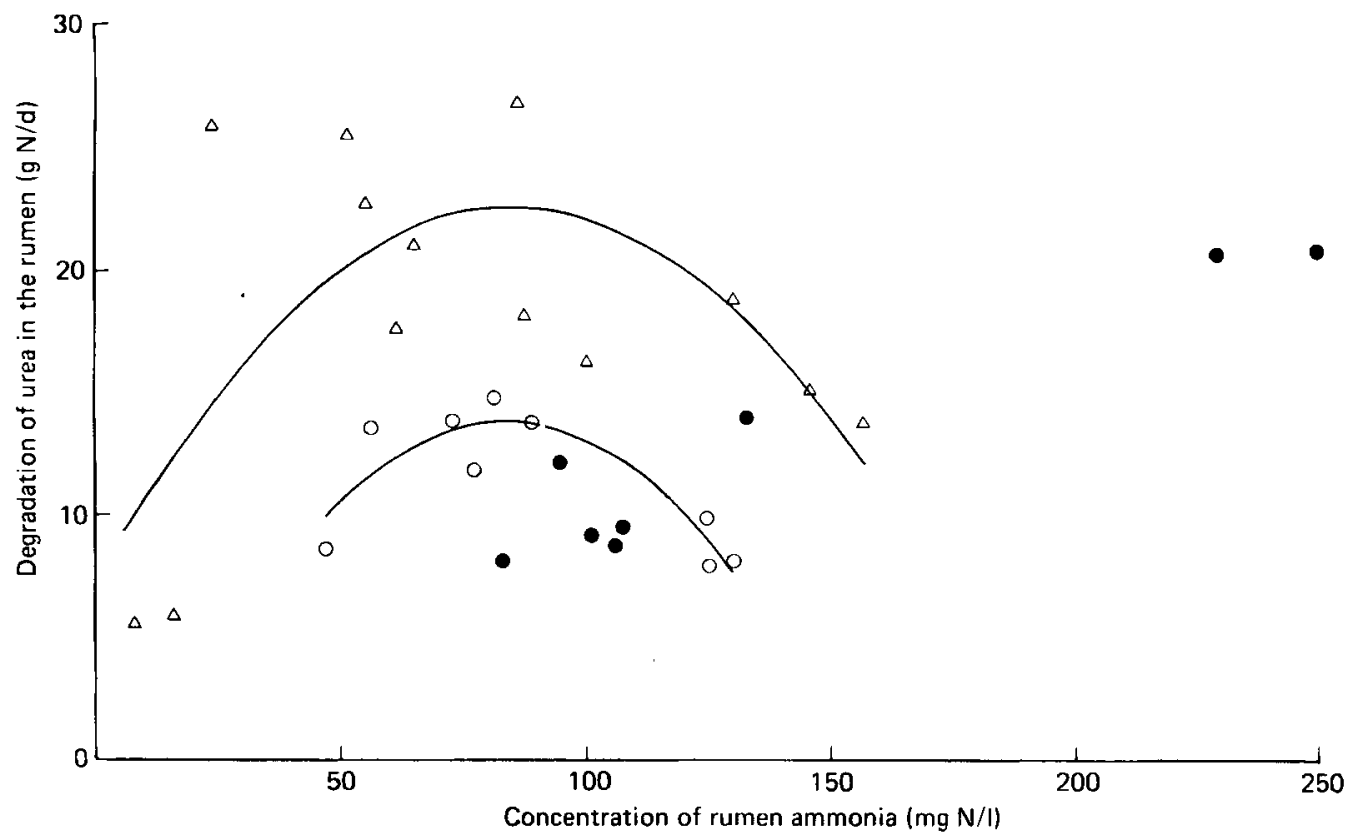

Fig. 5. Relationships between the degradation rate of urea in the rumen ( $\mathrm{g}$ nitrogen/d) and rumen ammonia concentration $(\mathrm{mg} \mathrm{N} / \mathrm{l})$ for cattle given diets with sucrose $(\triangle$, diets nos. 4-9), pasture-hay diets without sucrose or lucerne (Medicago sativa) ( $O$, diets nos. 1-3), or pasture-hay-lucerne mixtures (O, diets nos. IO-I2). For details of diets, see Table I. The relationships were described by the equations:

diet nos. 4-9 $y=7.21+0.357 x-0.00208 x^{2} \quad$ (residual SD (RSD) $5.57, R 0.67$ ), diet nos. I-3 $y=-7 \cdot 34+0.502 x-0.00297 x^{2} \quad$ (RSD 1.38, $R$ 0.90). 


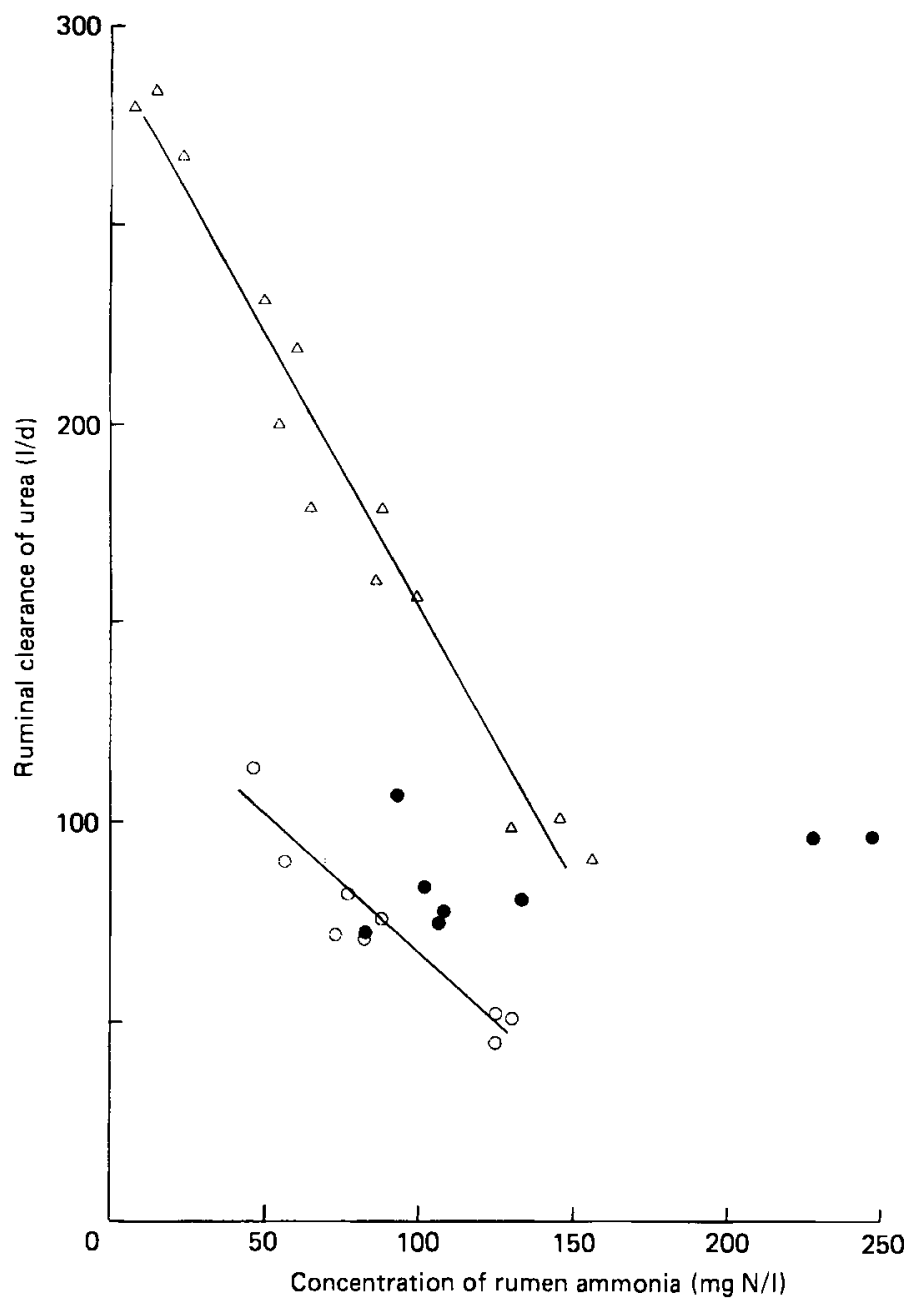

Fig. 6. The relationship between ruminal clearance of plasma urea $(1 / d)$ and rumen ammonia concentration (mg nitrogen/l) for steers given diets with sucrose $(\triangle$, diets nos. 4-9), pasture-hay diets without sucrose or lucerne (Medicago sativa) $(O$, diets nos. I-3), or pasture-hay-lucerne mixtures ( $\odot$, diets nos. 10-12). For details of diets, see Table I. The regression equations were:

diet nos. 4-9 $y=291-1 \cdot 37 x$ (residual SD (RSD) 13.7, $R$ 0.98),

diet nos. I-3 $y=136-0.687 x$ (RSD 9.97, $R$ 0.91).

Inclusion of the significant $(P<0.05)$ terms relating degradation of urea in the rumen $(D r, \mathrm{~g} \mathrm{~N} / \mathrm{d})$ to plasma urea concentration $(U, \mathrm{mg} \mathrm{N} / \mathrm{l})$ and rumen ammonia concentration $(A, \mathrm{mg} \mathrm{N} / \mathrm{l})$ within three dietary groupings accounted for $90 \%$ or more of the variance in each regression. The relationships were:

no sucrose or lucerne, diets nos. $1-3$

$$
\begin{gathered}
\left.D r=\mathrm{I} .06+0.194 U-0.00046 \mathrm{I} U^{2}-0.0917 A \quad \text { (residual SD (RSD) I. I0, } R 0.95\right), \\
( \pm 0.057)( \pm 0.000184)( \pm 0.015 \mathrm{I})
\end{gathered}
$$

pasture-hay-lucerne mixtures without sucrose, diets nos. I, IO, II, 12

$$
\begin{gathered}
\left.D r=10.6-0.068 U+0.000538 U^{2} \quad \text { (RSD I.29, } R 0.97\right), \\
( \pm 0.069)( \pm 0.000226)
\end{gathered}
$$


Table 5. Expt. 3. Intake of organic matter $(O M)$ and nitrogen, digestion of $O M$, and flow of non-ammonia- $N(N A N)$ and microbial $N$ from the stomach of steers given two diets*

Steer no....

Diet no....

OM intake $(\mathrm{kg} / \mathrm{d})$

Apparent $\mathrm{OM}$ digestion in rumen $(\mathrm{kg} / \mathrm{d})$

Dietary $N$ intake $(g / d)$

Flow of NAN from abomasum $(\mathrm{g} / \mathrm{d})$

Flow of microbial $\mathrm{N}$ from abomasum $(\mathrm{g} / \mathrm{d})$

Microbial synthesis/kg OM digested

Net gain of NAN in stomach $(\mathrm{g} / \mathrm{d})$

\begin{tabular}{cccc} 
I & 4 & 1 & 4 \\
7 & 7 & \multicolumn{1}{c}{ I } & 12 \\
$4 \cdot 56$ & $4 \cdot 56$ & $3 \cdot 69$ & $3 \cdot 69$ \\
$2 \cdot 18$ & $2 \cdot 3$ & $1 \cdot 5$ & $1 \cdot 68$ \\
$78 \cdot 4$ & $78 \cdot 4$ & $78 \cdot 4$ & $78 \cdot 4$ \\
$100 \cdot 2$ & $105 \cdot 0$ & $72 \cdot 1$ & $76 \cdot 2$ \\
$62 \cdot 1$ & $65 \cdot 2$ & $36 \cdot 4$ & $39 \cdot 4$ \\
$28 \cdot 5$ & $28 \cdot 2$ & $24 \cdot 1$ & $23 \cdot 5$ \\
$21 \cdot 8$ & $26 \cdot 6$ & $-6 \cdot 3$ & $-2 \cdot 2$
\end{tabular}

* For details of diets, see Table 1.

with sucrose, diets nos. 4-9

$$
\begin{gathered}
D r=-0.308+0.410 U-0.00108 U^{2}-0.147 A \quad(\text { RSD I.27, } R 0.99) . \\
( \pm 0.027)( \pm 0.00012) \quad( \pm 0.013)
\end{gathered}
$$

Negative linear relationships were evident, within diets nos. I-3 and 4-9, between ruminal clearance of urea in the rumen $(C 1 / d)$ and rumen ammonia concentration (Fig. 6 ). The relationships were described by the regression equations:

with sucrose, diets nos. 4-9 $C=29 \mathrm{I}-\mathrm{I} \cdot 37 \mathrm{~A} \quad$ (RSD 13.7, $R$ 0.98), no sucrose or lucerne, diets nos. I-3 $C=\mathrm{I} 36-0.687 \mathrm{~A}$ (RSD 9.97, $R$ 0.91).

The relationship was not significant for diets containing varying proportions of pasturehay-lucerne (diets I, IO, I I, I2) where clearance (mean \pm SEM) was 86 (土 I2) 1/d.

Entry rate of $\mathrm{HCO}_{3}-\mathrm{C}$ in the rumen

The entry rate of $\mathrm{HCO}_{3}{ }_{-}^{-} \mathrm{C}$ in the rumen tended to increase with increasing amounts of dietary sucrose, and to increase further with dietary urea (Table 3). For diets without sucrose, the rate of entry of rumen $\mathrm{HCO}_{3}-\mathrm{C}$ was increased by increasing the proportion of lucerne in the diet (Table 2).

\section{Digestion and microbial production in the rumen}

The addition of $1 \mathrm{~kg}$ sucrose to the lucerne-pasture-hay mixture together with additional urea infused into the abomasum (diet no. 7 compared with diet no. I2) was associated with marked increases in flow from the abomasum of non-ammonia- $\mathbf{N}$ and microbial $\mathbf{N}$ of approximately $28 \mathrm{~g} \mathrm{~N} / \mathrm{d}$ (Table 5). Approximately 0.4 of this increased flow could be accounted for by the increased degradation (from 10.9 to $2 \mathrm{I} \cdot 8 \mathrm{~g} \mathrm{~N} / \mathrm{d}$ ) of plasma urea in the rumen. Efficiency of microbial synthesis per $\mathrm{kg} \mathrm{OM}$ apparently digested in the stomach was increased by $19 \%$ (from 23.8 to $28.4 \mathrm{~g} \mathrm{~N} / \mathrm{kg} \mathrm{OM}$ ) by addition of sucrose to the diet.

\section{DISCUSSION}

In the experiments reported here it was found that for a given concentration of plasma urea, the rate of entry of plasma urea was $35 \%$ higher in steers given sucrose than in steers without sucrose. The results thus indicate that the fractional turnover rate of plasma urea was increased by dietary sucrose; this was primarily due to increased degradation of urea in the rumen (Fig. 4). Previous work with sheep showed that the relationship between plasma urea concentration and transfer of urea to the gastrointestinal tract depended on the nature 
of the diet (Cocimano \& Leng, 1967; Ford \& Milligan, 1970; Allen \& Miller, 1976) and the age of the animal (Allen \& Miller, 1976).

The proportion of the urea entry that is degraded in the gastrointestinal tract is determined by diet. In sheep the range is $0 \cdot 17-0.92$ (Cocimano \& Leng, 1967; Ford \& Milligan, 1970; Faichney, 1974a; Allen \& Miller, 1976; Nolan et al. 1976; Faichney \& White, 1977; Norton et al. 1978; Nolan \& Stachiw, 1979), with the lower values associated with high intakes of dietary urea (Allen \& Miller, 1976), protein (Cocimano \& Leng, 1967; Faichney $\&$ White, 1977) and high concentrations of plasma urea (Cocimano \& Leng, 1967). For dairy cattle given a grain-based diet, the proportion decreased from 0.93 to 0.59 with increased urea intake (Mugerwa \& Conrad, 1971). For a range of cattle breeds given a lowquality sorghum stubble, degradation in the gastrointestinal tract represented $0.48-0.9 \mathrm{I}$ of urea entry in the plasma (Norton et al. 1979). A similar range (0.34-0.89) was observed in the present experiments. Norton et al. (1978) found in sheep given grasses of low nutritive value that the amount of urea degraded in the post-ruminal tract was related to plasma urea concentration, while urea degradation in the rumen was dependent both on the plasma urea concentration and the secretion rate of saliva. In the cattle results reported here, degradation of urea in the post-ruminal tract was also closely related to plasma urea concentration for all diets (Fig. 3), in agreement with the suggestion of Norton et al. (1978) that passive diffusion of urea into the post-ruminal tract was the major factor controlling degradation.

The mean value for urea degradation in the rumen of steers given pasture-hay with infusions of urea into the abomasum (diet no. 2) was $8.6 \mathrm{~g} \mathrm{~N} / \mathrm{d}$, equivalent to $43 \mathrm{mg} \mathrm{N} / \mathrm{d} \mathrm{per} \mathrm{kg}$. This estimate was similar to that, $42-49 \mathrm{mg} \mathrm{N} / \mathrm{d}$ per $\mathrm{kg}$ body-weight, estimated for steers receiving a similar diet and intravenous urea infusion reported by Vercoe (1969) who used a technique which did not rely on radionuclide tracers. The limit to urea degradation in the rumen was attained at similar rumen ammonia concentrations $(50-100 \mathrm{mg} \mathrm{N} / \mathrm{l})$ in both Vercoe's (1969) study and in the present study. However, degradation of urea in the rumen was higher in diets with sucrose up to a rumen ammonia concentration of approximately I60 mg N/1 (Fig. 5). This finding supports the conclusion of Faichney (1974b) that the capacity of sheep to dispose of exogenous urea was enhanced when rumen ammonia levels were less than $200 \mathrm{mg} \mathrm{N} / \mathrm{l}$.

The proportion of urea degraded in the gastrointestinal tract which was attributable to rumen degradation was $0.50-0.75$ for steers given sucrose, $0.34-0.57$ for steers without sucrose (present study) and 0. 18-0.49 for steers given a low-quality sorghum hay (Norton et al. 1979). The proportion for cattle appears therefore to vary with diet, but tends to be higher than that, 0.08-0.53, reported for sheep (Nolan \& Leng, 1972; Nolan et al. 1976; Norton et al. 1978; Nolan \& Stachiw, 1979). Further information is required for sheep and cattle given the same diets before conclusions can be drawn about inter-species differences in the partition of urea degradation between rumen and post-ruminal tract.

For cattle receiving roughage diets without sucrose or urea supplements (diets nos. I, Io, II and I2), degradation of endogenous urea in the rumen was determined largely by plasma urea concentration, in agreement with the conclusions of Nolan \& Leng (1972) and of Norton et al. (1978), that most of the transfer of urea into the rumen can be attributed to salivary secretions. On the assumption that salivary urea concentration was 0.65 that of plasma urea (Bailey \& Balch, 1961), a ruminal clearance of urea of $1001 / \mathrm{d}$ would require a salivary secretion of $155 \mathrm{l} / \mathrm{d}$ if all the cleared urea were carried to the rumen via saliva. This is well within the range of values for saliva secretion in cattle (100-190 1/d) reported by Bailey \& Balch (I96I).

When the complex influences of varying dietary quality are removed by restricting consideration to diets of similar composition, it becomes apparent that both concentration of 
plasma urea and of rumen ammonia affect transfer of urea to the rumen of cattle. This observation is in accord with that of Kennedy \& Milligan (1978a), who found an inverse relationship in sheep between transfer of urea to the rumen and rumen ammonia concentration, with plasma urea concentrations varying between narrow limits.

The two variables, rumen ammonia concentration and ruminal clearance of urea, were closely related (Fig. 6) and thus gave approximately the same precision of prediction of urea degradation in the rumen when either varible was included in a multiple regression with plasma urea concentration within two dietary groups (diets nos. I-3 or diets nos. 4-9). However, by expression of rumen degradation of urea in terms of clearance, tentative conclusions can be drawn as to the relative importance of transport of urea by saliva and by movement across the rumen wall. Assuming that all urea transferred into the rumen was carried in saliva, the maximum value of urea clearance of $28 \mathrm{I} 1 / \mathrm{d}$ observed with diet no. 8 (Table 3) would require a salivary secretion rate of $432 \mathrm{l} / \mathrm{d}$ for its transport, and the observed relationships between clearance and rumen ammonia concentration (Fig. 6) would further imply that rumen ammonia concentration was negatively related to saliva production. $\mathrm{A}$ more reasonable explanation for these observations is that the lowest value of ruminal clearance of urea observed $(49 \mathrm{l} / \mathrm{d}$, diet 3) represented urea transported in 751 saliva, with clearance above $50 \mathrm{l} / \mathrm{d}$ ascribed to transfer of plasma urea across the rumen wall. Thus a maximum of 2301 plasma/d was cleared of urea which crossed the rumen wall (diet no. 8), representing 0.82 of total clearance to the rumen. This value is similar to the maximum, 0.90 , found in sheep given brome-grass (Bromus inermis) pellets (Kennedy \& Milligan, I978a).

The conclusion that transfer of urea into the rumen of sheep occurs principally by saliva has been derived from measurements in sheep given lucerne hay (Nolan \& Leng, 1972; Nolan et al. 1976) and low-quality pasture grasses (Norton et al. 1978), in which urea transfer to the rumen was low, representing a clearance of 4-1 I l/d. However, the suggestion (Kennedy \& Milligan, $1978 b$ ) that these low values of urea transfer were due to the limitation of urea transfer by high concentrations of rumen ammonia or low intake of digestible $\mathrm{OM}$ has now received support from the results reported here for cattle. In addition, a high clearance $(45 \mathrm{l} / \mathrm{d})$ has been recently reported by Nolan \& Stachiw (1980) for sheep given a mixture of wheaten chaff, lucerne and molasses. When ruminants are given a range of hay diets of differing nutritive value (e.g. diets nos. I and Io-12), the clearance of plasma urea across the rumen wall may on the one hand be limited by the low intake of digestible OM for low-quality forages, and on the other hand, by high concentrations of rumen ammonia for high-quality forages. Thus urea entering the rumen would be carried mainly in saliva when roughages are fed. Energy supplements, and perhaps pelleting in the instance of some grasses, result in the enhancement of urea transport across the rumen wall.

For a given group of diets of equivalent digestible OM, the relationship between ruminal clearance of urea and rumen ammonia concentration must be curvilinear, since clearance comprises a component (salivary transport) which is not dependent on ammonia concentration. This curvilinearity is evident in sheep (Kennedy \& Milligan, 1979) and presumably would also be evident in cattle with concentrations of rumen ammonia higher than those observed in the present experiments. Indeed the decreased slope of the relationship of clearance with rumen ammonia concentration for diets nos. I, 2 and 3 may be due to this curvilinearity, and therefore further results may reveal similar slopes for the relationship below a concentration of $90 \mathrm{mg}$ ammonia- $\mathrm{N} / \mathrm{l}$, with digestible $\mathrm{OM}$ intake affecting only the intercept of the regression.

Ruminal clearance of urea through the rumen wall has been equated with permeability by Engelhardt et al. (1978), which would imply that the functional surface area of the rumen mucosa through which urea movement occurs remains constant. However, the significant 
reduction in variance with the inclusion of the quadratic term $U^{2}$ in the relationships between degradation of urea in the rumen and the concentration of rumen ammonia and of plasma urea, implied that plasma urea concentration affected degradation of urea in the rumen in a way which was not completely accounted for by changes in clearance. Changes in the proportion of blood flow through arterio-venous anastamoses caused by an increase in plasma urea concentration, with a consequent change in the area of mucosa available for urea transport, is one possible explanation for this observation.

The increased ruminal clearance of urea associated with dietary sucrose provided a quantitatively-significant source of $\mathbf{N}$ available for microbial growth in cattle receiving abomasal urea infusions. The calculation that enhanced transfer of urea to the rumen in cattle given sucrose represented for only 0.4 of additional passage of microbial $\mathrm{N}$ from the abomasum implies that incorporation of ammonia into microbial protein was likely to be more efficient in steers given sucrose, associated with a decline in the concentration of ammonia and consequently in the rate of absorption of ammonia from the rumen. Calculations from Tables I, 2, 3 and 5 show that microbial $\mathrm{N}$ flow represented 0.42 of $\mathrm{N}$ entering the rumen in the diet and as endogenous urea for steers nos. I and 5 given diet no. 12 , but this value was 0.64 for the same steers given additional sucrose. Thus, the increased effciency of incorporation of ammonia into microbial protein in cattle given sucrose would result in the contribution of endogenous urea- $\mathrm{N}$ accounting for more than 0.4 of the additional microbial $\mathbf{N}$ synthesis. These results are in agreement with those for sheep given sucrose as reported by Potthast et al. (1977). However, when ruminants are given an energy supplement such as sucrose, the increased ruminal clearance of urea results in only a small gain of $\mathbf{N}$ in the rumen unless plasma urea concentrations are high. For a steer of the size used in the present experiments given a low-quality roughage with a consequently low plasma urea concentration of $50 \mathrm{mg} \mathrm{N} / 1$, a supplement of sucrose which caused an increase in clearance of $150 \mathrm{l} / \mathrm{d}$ would result in an extra $7.5 \mathrm{~g} \mathrm{~N} / \mathrm{d}$ being made available to the rumen micro-organisms, if the drop in plasma urea concentration caused by increased urea transfer to the rumen is ignored. Consequently, if microbial synthesis requires about $35 \mathrm{~g}$ $\mathrm{OM} / \mathrm{g}$ microbial $\mathrm{N}$ (Table 5), $260 \mathrm{~g}$ sucrose/d would be utilized for additional microbial synthesis.

In summary, it is evident that urea movement across the rumen wall may be substantial and is subject to control by the concentration of rumen ammonia and by some function of $\mathrm{OM}$ digestion in the rumen, but the identity and number of the sites of control of clearance is not clear.

The technical assistance of $\mathrm{Mr}$ C. R. Holmes is gratefully acknowledged. The author is indebted to Dr R. M. Seebeck for useful discussion.

\section{REFERENCES}

Allen, S. A. \& Miller, E. L. (1976). Br. J. Nutr. 36, 353.

Bailey, C. B. \& Balch, C. C. (196I). Br. J. Nutr. 15, 383 .

Bird, P. R. \& Fountain, R. D. (1970). Analyst, Lond. 95, 98.

Christian, K. R. \& Coup, M. R. (1954). N.Z. Jl Sci. Technol. 36A, 328.

Cocimano, M. R. \& Leng, R. A. (I967). Br. J. Nutr. 2r, 353.

Crooke, W. M. \& Simpson, W. E. (1971). J. Sci. Fd Agric. 22, 9.

Downes, A. M. \& McDonald, I. W. (1964). Br. J. Nutr. 18, 153.

Engelhardt, W. V., Hinderer, S. \& Wipper, E. (1978). In Ruminant Digestion and Feed Evaluation, [D. E. Osbourn, D. E. Bever and D. J. Thomson, editors]. London: Agricultural Research Council.

Faichney, G. J. (1974a). Proc. Aust. Soc. Anim. Prod. ro, 398.

Faichney, G. J. (1974b). Aust. J. agric. Res. 25, 599.

Faichney, G. J. (1975). In Digestion and Metabolism in the Ruminant, [I. W. McDonald \& A. C. I. Warner, editors]. Armidale, Australia: University of New England Publishing Unit.

Faichney, G. J. \& White, G. A. (1977). Aust. J. Agric. Res. 28, 1069. 
Ford, A. L. \& Milligan, L. P. (1970). Can. J. Anim. Sci. 50, 129.

Houpt, T. R. (1970). In Physiology of Digestion and Metabolism in the Ruminant, [A. T. Phillipson, editor]. Newcastle-upon-Tyne: Oriel Press.

Kennedy, P. M. (1978). Proc. Nutr. Soc. Aust. 3, 77.

Kennedy, P. M., Christopherson, R. J. \& Milligan, L. P. (1976). Br. J. Nutr. 36, 23 I.

Kennedy, P. M. \& Milligan, L. P. (1978a). Br. J. Nutr. 40, 149.

Kennedy, P. M. \& Milligan, L. P. (1978b). Can. J. Anim. Sci. 58, 814.

Kennedy, P. M. \& Milligan, L. P. (I980). Can. J. Anim. Sci. (In the Press).

Leng, R. A. \& Leonard, G. J. (I965). Br. J. Nutr. 19, 469.

Marsh, W. H., Fingerhut, B. \& Kirsch, E. (1957). Am. J. clin. Path. 28, $68 \mathrm{I}$.

Megarrity, R. G. \& Siebert, B. D. (1977). Analyst, Lond. 102, 95.

Mugerwa, J. S. \& Conrad, H. R. (1971). J. Nutr. Ior, 1331.

Nolan, J. V. \& Leng, R. A. (1972). Br. J. Nutr. 27, 177.

Nolan, J. V., Norton, B. W. \& Leng, R. A. (1976). Br. J. Nutr. 35, 127.

Nolan, J. V. \& Stachiw, S. (1979). Br. J. Nutr. (In the Press.)

Norton, B. W., Moran, J. B. \& Nolan, J. V. (1979). Aust. J. agric. Res. 30, 341.

Norton, B. W., Murray, R. M., Entwistle, K. W., Nolan, J. V., Ball, F. M. \& Leng, R. A. (1978). Aust. J. agric. Res. 29, 595.

Potthast, V., Prigge, H. \& Pfeffer, H. (1977). Z. Tierphysiol. Tierenähr Futtermittelk. 38, 338.

Seebeck, R. M. (1979). Sysnova Reference Manual, CSIRO, Div. Anim. Prod. Tech. Bull. (In the Press.)

Tan, T. N., Weston, R. H. \& Hogan, J. P. (1971). Int. J. appl. Radiat. Isotopes, 22, 301.

Vercoe, J. E. (1969). Aust. J. agric. Res. 20, 19 I.

White, R. G., Steel, J. W., Leng, R. A. \& Luick, J. R. (1969). Biochem. J. I4, 203. 